\title{
La pintura como exceso. Algunas consideraciones sobre la pintura mexicana desde la década de los ochenta hasta el presente
}

\author{
Painting as Excess. Some Considerations on Mexican Painting \\ from the Nineteen-Eighties to the Present
}

Artículo recibido el I2 de mayo de 20I6; devuelto para revisión el 20 de septiembre de 20I6; aprobado el 5 de mayo de 20I7, http://dx.doi.org/IO.2220I/iie.18703062e.2017.III.2604
Daniel Montero Fayad Universidad Nacional Autónoma de México-Instituto de Investiga- ciones Estéticas, México. hombre_tictac@hotmail.com

Líneas de investigación Historia del arte contemporáneo mexicano; crítica de arte en México y Estados Unidos.

Research Lines History of contemporary Mexican art; art criticism in Mexico and the United States.

Publicaciones más relevantes

El cubo de Rubik. Arte mexicano en los años go (Ciudad de México: RM/ Jumex, 20I4); "Un lugar común no es mi lugar: relaciones artísticas entre México y Estados Unidos en un mundo globalizado", Re-visiones, núm. 6 (2016); Código D.F. Arte y cultura contemporánea desde la Ciudad de México (México: Código, 2010).

Resumen El presente texto es una reconsideración histórica del estatus actual de la pintura en México, a partir de una serie de exhibiciones que sucedieron tanto en el país como en los Estados Unidos desde comienzos de la década de los años noventa. Se muestran además las tensiones de la crítica respecto a este tipo de práctica y cómo es que se produjo una imagen singular del arte en México con relación a la especificidad de ese medio. Por otra parte, se señala cómo es que el discurso sobre la pintura se construyó a partir de un diálogo internacional compartido entre México y los Estados Unidos que entró en crisis hacia finales de la década de los años noventa como producto de la globalización.

Palabras clave Pintura; arte mexicano; crítica de arte; neomexicanismo; identidad.

Abstract The present text is a historical reconsideration of the current status of painting in Mexico, gleaned from a series of exhibitions that took place both within the country and in the United States during the early I990s. It also shows the tensions of criticism regarding this type 
of practice and how it is that a unique image of art in Mexico was produced in relation to the specificity of this milieu. On the other hand, the article describes how the discourse on painting was constituted from a shared international dialogue between Mexico and the United States that came into crisis towards the end of the nineties as a product of globalization.

Keywords Painting; Mexican art; art criticism; Neomexicanism; identity. 


\author{
DANIEL MONTERO FAYAD \\ UNIVERSIDAD NACIONAL AUTÓNOMA DE MÉXICO \\ INSTITUTO DE INVESTIGACIONES ESTÉTICAS \\ MÉXICO
}

\title{
La pintura como exceso \\ Algunas consideraciones sobre la pintura mexicana \\ desde la década de los ochenta hasta el presente
}

$\mathrm{E}$

n los últimos cinco o seis años la pregunta por la pintura, las prácticas pictóricas o incluso "lo pictórico" ha resurgido en México desde diferentes frentes. Se han creado grupos de pintores jóvenes como Los Hamsters ${ }^{\mathrm{I}}$ y lugares de exhibición como la galería Diagrama. ${ }^{2}$ Además, han aparecido críticos de arte que en sus escritos defienden a ultranza la pintura, como Avelina Lésper, quien además dirigió un programa de televisión llamado El milenio visto por el arte, para el cual seleccionó a 34 pintores de diferentes generaciones, ${ }^{3}$ a quienes entrevistó y les comisionó una obra para que formara parte de la colección Grupo Milenio. Por otro lado, a finales de 2015 y comienzos de 2016 Octavio Avendańo dio una serie de pláticas y organizó debates respecto a la pintura a propósito de la exhibición "Efectos especiales". ${ }^{4}$ De la misma manera, en otros lugares como Monterrey, Guadalajara y Oaxaca, ${ }^{5}$ cada

I. Al respecto véase http://www.jornada.unam.mx/20I4/oI/o6/cultura/aognicul.

2. Para mayor información consúltese sic.cultura.gob.mx/ficha.php?table=galeria\&table_id= 40I y www.timoutmexico.mx/ciudad-de-mexico/arte/diagrama.

3. Arturo Rivera, Paulina Jaimes y Daniel Lezama, entre otros, véase http://arte.milenio.com/.

4. Véase www.excelsior.com.mx/periodico/flip-expresiones/I4-OI-20I6/portada.pdf.

5. Sólo para nombrar un caso, en 20I4, en el Salón de Octubre de Guadalajara, un evento de pintura que se celebra en esa ciudad cada año, algunos artistas desmontaron sus obras porque el premio se declaró desierto. Un ańo después se obligó a la artista Susana Paulina Casillas a descolgar su obra Tus actos gritan más fuerte que tu voz porque había copiado una pintura de Tanya 
uno con una tradición pictórica diferente, se siguen dando batallas y presentando resistencia a favor de la representación artística y la función de la pintura en la contemporaneidad.

$\mathrm{Al}$ parecer esta reactivación del debate sobre la pintura se ha dado gracias a la pérdida de especificidad del medio en el arte contemporáneo y a la pregunta por el papel de la pintura en el campo artístico local-global, entre otros aspectos. Es claro que la noción de arte contemporáneo ${ }^{6}$ trastocó las maneras de entender el arte en relación con su práctica, la cual establece nuevas formas de producción, circulación y consumo. La especificidad del medio cambió hacia la del sitio, para luego cuestionar el contexto, la localización y la deslocalización de las prácticas, y por supuesto, su carácter político. Por otro lado, la transición que se dio en las prácticas artísticas, de pintura, dibujo y escultura, principalmente, hacia el objeto artístico y el proyecto de arte en la década de los noventa, replanteó la relación que los artistas tenían con su práctica porque ya no era necesario "hacer" para "producir". ${ }^{7}$

Precisamente, lo que se cuestiona es el estatus del arte y sus implicaciones a partir de dicha especificidad basada en las prácticas e imágenes pictóricas sin siquiera considerar su categoría como imágenes. En efecto, este texto es una contribución para evidenciar la manera en que se ha comprendido la pintura en México desde mediados de los años ochenta hasta el presente, a partir del análisis de algunas exhibiciones que han marcado hitos en las formas de comprender

Shatseva de internet, una artista que había subido a la red un video en el cual mostraba cómo realizaba sus pinturas.

6. Este texto es un intento por mostrar cómo es que la pintura, desde su especificidad como medio, no está desarticulada de la producción del arte contemporáneo. Sin embargo, la relación que se puede establecer entre la práctica de la pintura y otras formas artísticas es un debate que aparentemente aún no se ha cerrado, sobre todo por la dificultad de definir qué es arte contemporáneo. Para un ejemplo interesante del debate sobre lo contemporáneo, véase Alexander Alberro, ed., ¿Qué es el arte contemporáneo hoy? (Pamplona: Universidad Pública de Navarra, 20II).

7. Esto se puede ver con claridad en la exposición "Acné o el nuevo contrato social ilustrado", llevada a cabo en el Museo de Arte Moderno de la Ciudad de México en 1995. Muchas de las obras que se exponían allí tenían que ver más con objetos encontrados y ensamblados que con obras realizadas por los artistas. Por ejemplo la obra Anillos-vitaminas-shampoo de Sofía Táboas que consistió en una serie de cajas transparentes rellenas de shampoo sobre las cuales se colocaron anillos de plástico o la de Eduardo Abaroa, Irrupción metafísica de los hombres desperdicio, en la cual presentó una pila de revistas pornográficas con un espejo y unos juguetes de plástico (Carlos Ashida, Patrick Charpenel y Teresa del Conde, Acné, o, El nuevo contrato social ilustrado: Eduardo Abaroa, Marco Arce, Abraham Cruzvillegas, Daniel Guzmán, Sofía Táboas, Pablo Vargaslugo (México: Museo de Arte Moderno, 1995). 
esta práctica en el país, entre ellas la exposición "Mito y magia en América: los ochenta", llevada a cabo en el Marco de Monterrey en I991 y "Cinco continentes y una ciudad", realizada en el Museo de la Ciudad de México, exposición que tuvo tres versiones entre 1998 y $2000 .{ }^{8}$ Ésta resulta un aporte para entender dicho medio en la contemporaneidad que será pensado ya no como privilegiado o céntrico, sino más bien como un exceso, como dispersión y fragmento.

La selección de las exhibiciones a las que hago referencia obedece a una particularidad: en todas se piensa la pintura como una tensión argumental que surgió con la globalización, en particular con el intercambio comercial y simbólico con los Estados Unidos. El asunto tiene que ver con la manera en que la pintura se transformó, no sólo porque sus "formas" hayan cambiado, sino también por la "manera" en que su comprensión se encontraba en una tensión discursiva producida por la crítica internacional ${ }^{9}$ — que en momentos reconfiguraban nuevas preguntas por la subjetividad en la dislocación de la noción de identidad - causada por los flujos de la globalización. Es imposible pensar que la pintura y todas sus cualidades históricas como originalidad, autenticidad, comunicabilidad y autoría no se iban a transformar en el mundo contemporáneo lleno de imágenes. Sin embargo, el diálogo histórico que mantiene esa práctica con su propia tradición, e incluso con el mismo concepto de arte, hace que la pintura siempre esté echada hacia atrás cuando se trata de proyectar como presente. En ese sentido, la relación que tiene la pintura con la imagen contemporánea no es menor porque singulariza y detiene, en un ejercicio reflexivo, el mundo de imágenes.

\section{La pintura como parte de un proyecto}

En 2015, se presentó en el Museo Rufino Tamayo de la Ciudad de México la exposición "Relato de una negociación” del artista belga-mexicano Francis Alÿs

8. Las tres exposiciones tuvieron catálogos impresos. Véase Museo de la Ciudad de México, Cinco continentes y una ciudad: Salón Internacional de Pintura (México: Gobierno del Distrito Federal, 1998); Museo de la Ciudad de México, Cinco continentes y una ciudad: segundo Salón Internacional de Pintura (México y Guadalajara: Gobierno del Distrito Federal/Baños Venecia, 1999); Museo de la Ciudad de México, Cinco continentes y una ciudad: tercer Salón Internacional de Pintura (México: Gobierno del Distrito Federal, 2000).

9. Como se verá en este texto son interesantes los casos de los críticos Edward Sullivan y Francesco Pellizzi. 
(Amberes, 1959). ${ }^{10}$ En la entrada del museo en una televisión del vestíbulo se veía y escuchaba cómo una sierra eléctrica cortaba, hasta el muro, una pintura de pequeño formato que mostraba un paisaje de una selva bastante convencional. Más adelante, justo a la entrada de las salas se veía la pintura dividida y el corte. La obra The Cut (1993-20I5) (fig. I) ponía en cuestión la función de la pintura en toda la exposición precisamente por la violencia explícita que se le ejercía al formato y al medio, ya no al interior del aparato de representación sino en el límite, en la relación pintura-cuadro-muro. ${ }^{\text {II }}$ Además, la obra ponía en tensión dos momentos importantes del arte mexicano por la "duración" de su proceso: si en 1993 para Alÿs era pertinente hacer una pintura de la selva, en 2015 era necesario realizar un corte como un comentario, no sólo a su pintura sino a la obra que produjo desde entonces.

Curiosamente, a partir de esa obra, gran parte de la exposición entraba en conflicto porque muchas de las piezas allí expuestas tenían que ver más con la idea de reunir y de juntar dos extremos que con la separación. Así, en la serie Puentes (2006-2008) se conjugaban de manera metafórica dos extremos territoriales (como, por ejemplo, Cuba-Estados Unidos o Marruecos-España) separados por cuerpos de agua y que pueden considerarse antagónicos en sus relaciones políticas.

Precisamente por eso resulta tan interesante que la exhibición iniciara con una obra que cuestiona la condición de la pintura de esa forma violenta en la cual una pintura tradicional es "abierta", destripada hacia afuera y desde afuera, con una acción real que va "más allá" de la superficie y que, de manera recíproca, introduce la realidad en el cuadro mientras que se establece la naturaleza representacional de la pintura. "Meter" la sierra en la pintura y más allá de ella hacia abajo y hacia arriba, pero también más adentro del plano pictórico, hace que se produzca una expansión de ese plano hacia afuera, pero también que la "realidad" entre allí. Además, el video que registra la acción pone en tensión la temporalidad del performance, de la pintura y del residuo como huella. Es en ese sentido que se podría preguntar cuál es la función de la pintura en toda la exposición. Para ser más claros la pregunta concreta que me gustaría formular

Io. Cuauhtémoc Medina, ed., Relato de una negociación (Ciudad de México: Instituto Nacional de Bellas Artes, 2015).

II. Resulta claro que en la obra hay un comentario a las de Lucio Fontana en las cuales se hace una incisión sobre un lienzo preparado con color, Concetto spaziale, attesa (I959). Sin embargo, la acción de Alÿs trasciende ese gesto superficial al entrar de lleno al muro, en lugar de quedarse en la superficie representacional del cuadro. 


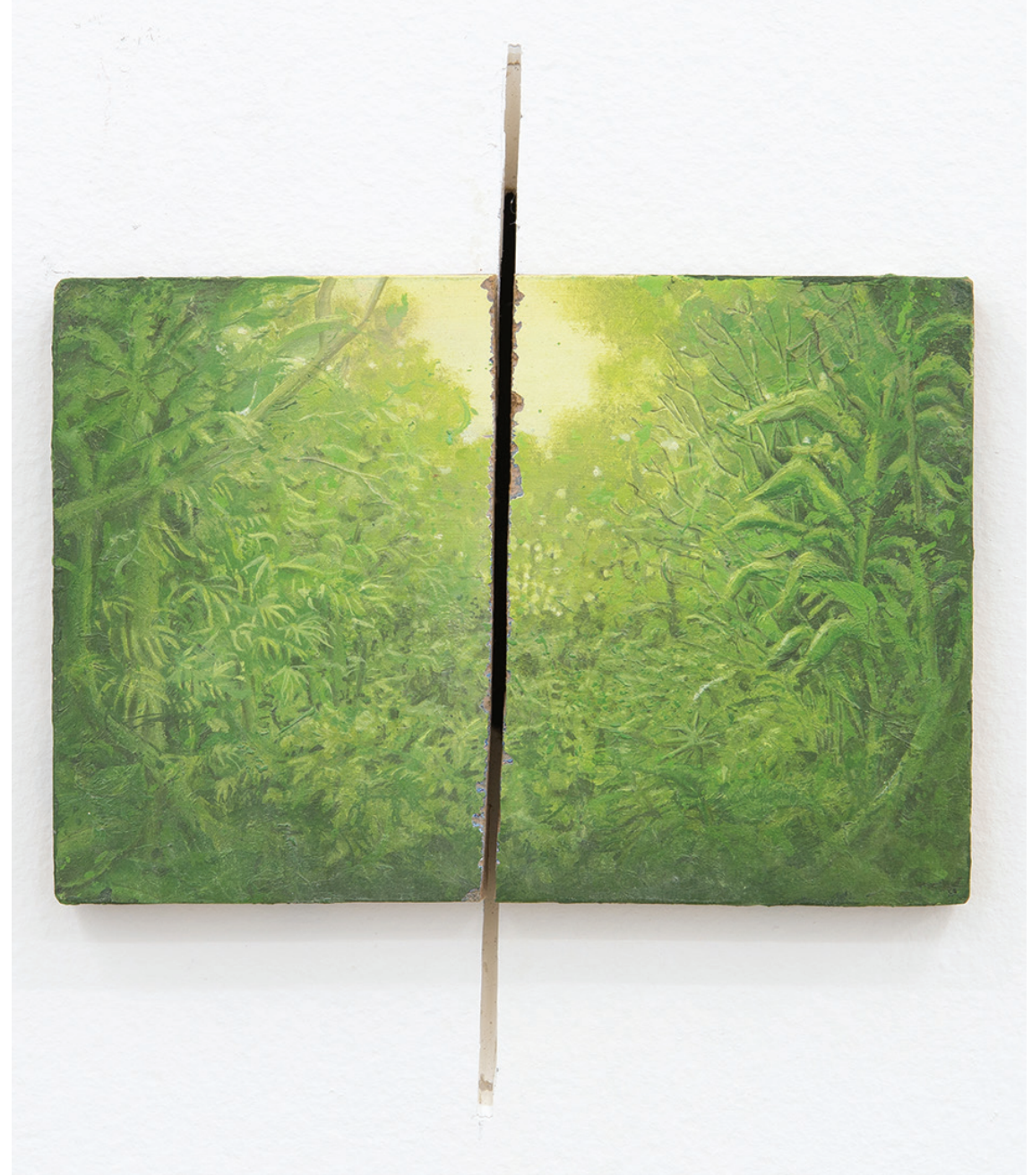

I. Francis Alÿs, fragmento de The Cut, 1993-2015, acción, óleo sobre tela y video. Cortesía de Francis Alÿs.

es si la exposición de Alÿs puede considerarse un epítome del papel de la pintura en el arte contemporáneo y cómo funcionaría.

Ahora bien, para Cuauhtémoc Medina lo que ha entrado en crisis no es la pintura en sí misma sino el dispositivo del "cuadro", cuestionado fuertemente en el siglo xx, pero que en el siglo Xxi, con la forma de producción 
que parte de un proyecto, adquiere un lugar periférico dentro de la producción del artista,

En lo que va del siglo Xxi, varios de los proyectos de Alÿs han coincidido en interrogar la relación entre la escenificación y el registro de acciones artísticas y la labor de la imaginación y factura de la pintura. Desafiando la dicotomía que atribuye a la pintura una condición solipsista y un ethos meramente autorreferencial, y a la acción un rango de intervención simple e inmediata, Alÿs ha tejido una variedad de proyectos poético-político-pictóricos, donde la pintura opera como un medio entre medios, dentro de una práctica que ocurre en relación con una movilización específica de agentes sociales y contextuales, formas diversas de imaginación, y espacios dotados de una significación ejemplar. Superpuestos en el tiempo, pero distribuidos en tres continentes, los proyectos ofrecen perspectivas complementarias, pero imposibles de subsumir a un principio unificado. Se ofrecen, por consiguiente, como un ensayo en la práctica sobre las posibilidades de articulación del binomio de la pintura y la acción.

En un cierto sentido, esas tres series (Puentes, 2006-2008, Tornado, 2000-2010, Afganistán, 20II-20I4) plantean modalidades muy distintivas de cómo formular un "más allá" de la práctica pictórica usual para atisbar los modos en que la imaginación y trabajo sobre la tela y el papel pueden servir a conjuntos más amplios de imaginación y reflexión. Bien vistos, esos proyectos fueron ocasiones para plantear tareas a la pintura que a la vez acompañaban y excedían el impulso político de sus proyectos de referencia. Son los capítulos de un ensayo virtual sobre las relaciones posibles de la pintura y la acción. ${ }^{\text {I2 }}$

El argumento de Medina es convincente en tanto reflexiona sobre la inexistencia, al menos en esas obras de Alÿs, de una especificidad del medio y las pinturas aparecen siempre con una doble naturaleza, lo cual las hace aparecer como ambiguas en una relación más amplia a favor de un proyecto que sería, en este caso un ejercicio de pensamiento. Las pinturas formarían parte de ese ejercicio, ya no como el centro ni como un momento preparatorio, sino como un momento más. Es claro que Medina está participando del debate local sobre la "muerte" de la pintura pero tampoco le da un lugar privilegiado. Sin embargo, creo que hay otra discusión velada que tiene que ver con la manera en que se ha comprendido la pintura en los últimos 30 años: evidentemente en el sentido en que Medina la entiende, la pintura no "representa" nada como solía hacerlo, ya

I2. Cuauhtémoc Medina, "Un arte enjambre", en Relato de una negociación, 29. 
sea como subjetividad, como localidad o como temporalidad, entre otras cosas. En ese sentido ya no habría un espacio pictórico "representativo" por fuera del proyecto, ni seguiría ninguna agenda. Las obras de Alÿs, como el mismo Medina lo señala, se refieren a un lugar, pero no "son del lugar", es decir, hay un distanciamiento con los esencialismos en los que se había circunscrito la pintura en la década de los ochenta como se verá más adelante.

Desde mi punto de vista, lo que ocurre es un regreso de la superficialidad del medio en el que a veces se "fijan" otras imágenes o que a veces ese medio sirve como un punto de inflexión de otras y no es sólo un "medio más" dentro del proyecto. Sin embargo, me quiero detener aquí para mostrar que esa situación ha sido parte de un proceso histórico que tiene que ver con los medios, con la historia de la pintura en México, pero también con el contexto de globalización y la posibilidad de entender el arte contemporáneo en un ámbito de circulación. En definitiva, cómo entender la pintura en esas circunstancias.

\section{Cinco continentes y una ciudad: una exposición global}

De 1998 a 2000 se realizaron tres versiones de una exposición sin precedentes para la Ciudad de México; "Cinco continentes y una ciudad: Salón Internacional de Pintura"; exhibidas en el Museo de la Ciudad, intentaban mostrar un panorama de la pintura mundial: África, Asia y Oceanía, América, Europa y la Ciudad de México como lugar en el que se articulaba toda la exhibición. ${ }^{13}$ La curaduría de cada uno de los continentes se comisionó a un curador distinto. Ese Salón resulta importante porque tal vez fue el primer evento global en la Ciudad de México, un poco en contravía de la tendencia de bienales de arte contemporáneo de ese momento. Esto se dio en un marco de modernización de la Ciudad en el primer gobierno del PRD, el de Cuauhtémoc Cárdenas, después de que se cambiara la ley para que el jefe de gobierno de la ciudad fuera designado por elección popular. ${ }^{14}$ La exhibición, iniciativa de la artista Marta Palau, se describió de la siguiente manera:

13. Cinco continentes y una ciudad: Salón Internacional de Pintura.

I4. Para conocer esto a detalle véase María Fernández, "Transnational Culture in the End of the Millennium", en Cosmopolitanism in Mexican Visual Culture (Austin: University of Texas Press, 20I4), 274-30I. 
El conjunto de obras que aquí veremos, un primer encuentro de arte contemporáneo, nos ayudará a entender el panorama internacional del arte. Cinco continentes y una ciudad es un acercamiento a las reflexiones de la nueva pintura en todas sus acepciones. ¿Por qué pintura? Es la primera pregunta que me hacen sobre el salón, en este momento en que casi lo único que se ve en los centros del arte de vanguardia son instalaciones. Entonces ¿por qué ir en contra de la corriente? ¿Por qué no pintura, más instalaciones, más otras manifestaciones de la actualidad? La pintura es un ejercicio que acompaña al hombre desde sus albores: petroglifos, pinturas rupestres y jeroglíficos — predecesores de los caracteres de la escritura- se repiten en las diferentes culturas de los cinco continentes. Volver nuestra mirada a la fuente de donde todo brota, la pintura, es inevitable. En arte se avanza, se dan rodeos y se retrocede continuamente. A través de este caminar de ida y vuelta nos reconocemos, aprendemos y cambiamos. Es necesario atender las fuentes más que a las modas. ${ }^{\text {I5 }}$

Precisamente, la justificación de hacer un salón de pintura era de por sí ya bastante problemática porque el asunto de la especificidad de los medios, así como la idea de reunirlos a todos bajo la palabra salón, parecía anacrónico. Sin embargo, en México tenía sentido pensar en esos términos porque la organización de eventos de esta magnitud, panorámicos y abarcadores, ya se había vuelto una tradición en la ciudad, misma que se constituyó durante la década de los sesenta. ${ }^{16}$ Parecería entonces que la idea de "salón" de "pintura" estuviera dada por una relación "natural" que en el texto de Palau se vincula con pasados remotos y con cierto tipo de misticismo trascendental además de pensar la pintura como una suerte de fuente de donde "todo brota" y que es desde allí desde donde se puede compartir algún tipo de experiencia artística.

Curiosamente ese carácter esencial que Palau le da a la pintura no es transferible, al calificar las otras manifestaciones artísticas, en particular las instalaciones, como pura moda. En ese sentido, la pintura sería un arte superior, y

I5. Marta Palau, "Cinco continentes y una ciudad", en Cinco continentes y una ciudad: Salón Internacional de Pintura, 2.

I6. Está muy documentada la relación entre Estado y Salón durante las décadas de los años sesenta, setenta y ochenta. Véase María Teresa Favela Fierro, "La crítica de arte en México a través de los salones y bienales nacionales de escultura del Instituto Nacional de Bellas Artes", Discurso Visual, núm. 35 (20I5), consultado el I5 de enero de 2016, en http://www.discursovisual.net/ dvweb35/TT_favela.html; así como Sol Álvarez, "Tutela estatal y nuevas tendencias/I950-I960", Discurso Visual, consultado el is de enero de 20I6, en http://discursovisual.net/raepoca/dvwebog/ artog/artog.html, entre otras. 
lo que quedaría entonces como un elemento fundamental sería que la "pintura” comparte globalmente una esencialidad incuestionable, de ahí que llevar a cabo un salón de pintura sea para Palau lo más normal porque es desde ese medio y formato como se pueden encontrar rasgos comunes.

Resulta muy claro que para algunos curadores de las tres versiones que tuvo la exhibición el asunto no era menor, por lo cual se encargaron de cuestionar radicalmente la propuesta. Por otro lado, las formas de anunciar cada una de las curadurías de los respectivos continentes variaba según el curador, asunto del que me ocuparé luego. En la primera versión, en 1998, la objeción más grande sobre el formato y la idea de pintura para un evento de esta naturaleza la ofreció Okwui Enwezor, curador de la sección africana.

Hay algo de paradójico en la convicción de esta exposición en una época de apertura como la que vivimos, en la que fluyen, aunque no necesariamente, redes de cadena entre ideas, prácticas, lugares y personas, donde una podría seguir reproduciendo las múltiples perspectivas de las actuales prácticas artísticas no sólo teniendo en cuenta la noción geográfica: "Cinco continentes y una ciudad"; sino también una especificación de un lenguaje particular: la pintura.

Desde que la gente de todo el mundo no siente ya la necesidad de estar restringida a una frontera, ¿por qué debería el arte o incluso una exposición estar sin embargo confinada? Sin duda, muchos cambios han atendido nuestras reacciones y también han tenido lugar cambios dentro de la práctica del arte mismo. Entonces ¿por qué pintar? ¿qué significa, de hecho, pintar hoy en día? [...] cómo reponer y estructurar la pintura no sólo en términos del lenguaje pictórico, sino también cómo ha sido reformulada geográficamente. [...] Quizá, el mismo destino de no servir para nada le espera también a esta exposición. A pesar de todo, el contexto de México, con una particular visión histórica de la pintura, presenta un reto interesante. Tal vez aquí es donde yace su raison d'etre. ${ }^{17}$

Y más adelante,

La pintura actual, a diferencia del neo-expresionismo grandilocuente y agresivo de los ańos 8o, parece tener otros objetivos. Incluso hay una vuelta a las estrategias formales del pasado, especialmente en la atención que muchos artistas están dedi-

17. Okwui Enwezor, "Impresionante perversidad", en Cinco continentes y una ciudad: Salón Internacional de Pintura, 3 I. 
cando al retrato, al paisaje y más recientemente al campo de color y a la abstracción geométrica. Incluso parece que hay también una incertidumbre hacia los objetivos de los trabajos mismos y un vacío que separa los géneros históricos y lo que los artistas están articulando hoy en día. [...] Mirando incluso los esfuerzos de los últimos años, mi conclusión sugiere una tendencia hacia una especie de cínico reciclaje de estilos, pero sin límite alguno. [...]

A pesar de esto, hay otras prácticas en la pintura que acechan una experiencia diferente, que hace diferentes preguntas, infundiendo a la pintura una poderosa poesía, magnética que no se predica dentro del modelo heroico de la pintura elevada a tan alto grado por el expresionismo abstracto de los cuarenta y los cincuenta.[...] Hoy los pintores jóvenes trazan nuevos espacios, exploran en técnicas personalizadas otras maneras de ver el mundo o representar experiencias. ${ }^{18}$

Es claro que para Enwezor la exhibición "Cinco continentes" no tiene mucho sentido y que la propuesta, a largo o mediano plazo, estaría condenada a fracasar. La explicación que da para ello depende de dos factores: en primer lugar el asunto geográfico como procedencia determinante de la producción artística y en segundo, la especificidad del medio pictórico como esencialismo artístico. Al considerarlos se puede pensar en la inconsistencia del proyecto en la medida en que el mundo contemporáneo ya no responde a ninguno de los dos. Depende más bien de la movilidad de la noción de territorio y nación modernos, cuestionados fuertemente por las diferentes migraciones provocadas por la globalización y por las crisis de los Estados-nación a finales de los noventa. ${ }^{19}$ Por otro lado, los procesos artísticos del arte contemporáneo han hecho imposible pensar que habría un medio privilegiado sobre otros y que la pintura, además de todo, parecería una especie de restricción que no sólo confinaría a un marco el "movimiento" sino que limitaría históricamente al arte a su misma tradición. Lo interesante del argumento es que para el curador la raison d'etre de la exposición es que se haga en el contexto de México "(un país) con una particular visión de la pintura". Parece entonces que la historia de la pintura se ve singularizada por el contexto mexicano y eso es lo que permite

I8. Enwezor, "Impresionante perversidad", 32-33.

19. Sobre este tema se ha publicado gran cantidad de información. Con el fin de consultar algunas referencias véase Nikos Papastergiadis, The Turbulence of Migration: Globalization, Deterritorialization and Hybridity (Cambridge: Polity Press, 2000) y Markus Pohlmann, Nonghoe Yang y Jong-Hee Lee, eds., Citizenship and Migration in the Era of Globalization (Heidelberg: Springer, 20I3). 
hacer una exposición de pintura aquí, es decir, continuar la tradición, pero por otra vía. Restituir el medio, así como el lugar, sólo tenía sentido para Enwezor en un diálogo con la historia del lugar, o más bien, de cómo es que se ha representado históricamente el arte mexicano a partir de sus mismos medios.

¿Cómo se emparentaría entonces la tradición de la pintura local con la nueva pintura contemporánea?, o más bien: ¿para qué seguir pintando? ¿Qué tipo de aporte al medio podría surgir a partir de los diálogos local-global, sujetocontexto, historia-tradición, medios-formas? La cuestión aquí tiene que ver también con cómo es que el curador lee los contextos particulares para afrontar un evento de esta naturaleza: para él, únicamente obras que tienen una fuerte carga subjetiva — que se ve sintetizada en una estrategia formal, que llevan un poderoso contenido y que producen significado, es decir, las que generan una metanarrativa-, son las que podrían funcionar en la muestra. En la selección que realiza el curador, sin embargo, parecería que lo que ocurre es un vaciamiento de contenidos en los medios, que son usados para referir, al mismo tiempo, el asunto de la identidad. Se podría entonces preguntar, ¿cuál sería el mejor "medio" que exprese esa condición identitaria?

Evidentemente la pintura ha dejado de funcionar en ese sentido, sobre todo después de la pintura de la década de los ochenta, como se verá más adelante. El asunto tiene que ver con la manera poco crítica en que ese tipo de pintura afronta el pasado y el presente (su pasado y su presente) mostrando sólo sus efectos, sin siquiera producirlos. Pinturas "sin historia, sin compromiso", decorativas. Precisamente, la pregunta que se le hace al "medio" tendría que ver con la posibilidad de tener, no sólo contenidos, sino que éstos sean "contemporáneos": la relación entre el tiempo/espacio exterior (la experiencia subjetiva de la realidad) se debería desplegar en ese medio.

El texto de Enwezor pone en cuestión el papel de la pintura en el arte producido a finales del siglo, y al mismo tiempo el reemplazo de las formas de vida y de entendimiento del arte en general, en el proceso de globalización. Sin embargo, y a pesar de las consideraciones de otros curadores como Gerardo Mosquera en esa misma edición del evento, ${ }^{20}$ la sección mexicana exhibió básicamente pintura-pintura sin mucho problema, en particular algunos de los artistas más conocidos de finales de la década de los ochenta y comienzos de los noventa, como Germán Venegas (1959) y Mónica Castillo (1961). En esta sección no se

20. Gerardo Mosquera, "América", en Cinco continentes y una ciudad: Salón Internacional de Pintura, 93-97. 
problematiza tanto la relación entre arte-pintura-globalización sino que más bien se hace una reflexión sobre cómo es que ha cambiado la pintura en el país. Y no era para menos. En efecto, y a pesar de que para esos años la pintura podía ser un medio más entre otros para artistas más jóvenes, aún muchos de ellos de diferentes generaciones seguían pintando y no se cuestionaban la tradición pictórica misma. Eso se puede apreciar claramente en la presentación del catálogo firmada por Rita Eder. ${ }^{2 I}$

La narración de Eder en ese texto es sorprendente por la manera en que construye un argumento histórico para justificar la aparición de la pintura en la década de los ochenta con relación a las propuestas de los artistas más explícitamente politizados de la década previa a los setenta, pero no explica cómo es que esa pintura desplegó nuevas maneras de entender el arte en la década siguiente. El argumento que se refiere a que ya no se puede confinar la pintura a sus "medios tradicionales" y que otros medios como el cine y la foto han alterado no sólo la manera de realizarla sino de percibirla vuelve a aparecer, pero esta vez la explicación dada es completamente local, perteneciente a una tradición mucho más restringida. La pintura de ese momento al parecer responde a lo que Eder llama la "apropiación" — a diferencia de la "influencia" como procedimiento crítico en la recombinación de imágenes y la reaparición de temas que podían considerarse obsoletos, como el retrato. Sin embargo, no dice cuáles son las consecuencias críticas de ese procedimiento ni cómo han alterado las maneras de entender el arte para ese momento. El texto, que cierra de manera apresurada luego de hacer una breve reseña de los artistas que participaron en la sección, reconoce que "hay desde luego una decisión de explorar un lenguaje más internacional, deshaciendo clichés de identidades culturales congeladas o establecidas y manuales de símbolos gastados" ${ }^{22}$

Es interesante constatar que estos autores cuentan las respectivas historias de la pintura de los años noventa y las vinculan a diferentes tradiciones. Para Enwezor la pintura que se hace a finales del milenio está más emparentada con la de finales de los cincuenta de los Estados Unidos (lo que él llama el new color-field), pero sin ningún contenido crítico, respondiendo más bien a la moda y a la decoración, a diferencia de la violencia expresiva de las pinturas de los años ochenta. Sin embargo, y como ya lo había anotado, hablar de "pintu-

2I. Rita Eder, "Apropiaciones: figura, espacio y percepción en algunos artistas mexicanos de los noventa", en Cinco continentes y una ciudad: Salón Internacional de Pintura, 219-220.

22. Eder, "Apropiaciones", 22I. 
ra" en términos estrictos no tiene sentido para 1998. Por otro lado, para Mosquera, el arte de los años noventa está más emparentado con el de los setenta, la pintura de los ochenta fue una especie de "bache" en esa tradición, y lo que a él le interesa es la pintura que cuestiona los "medios". ${ }^{23}$ Eder analiza parcialmente las relaciones entre el arte de los ochenta y noventa sin emparentar a este último con el arte de los años setenta por lo que pareciera haber una continuidad en esos últimos veinte años. ${ }^{24}$ Además, no pone en duda el papel de la pintura como medio en esa contemporaneidad. ${ }^{25}$ Así, la pintura de los años ochenta parece que había generado, hasta ese momento, y al menos según su opinión, una suerte de continuidad gracias a las propuestas de esa misma déca$\mathrm{da}$, aunque hubo un cambio institucional importante en los noventa.

En "Cinco continentes y una ciudad", el primer intento por hacer una exhibición global en la Ciudad de México, se generó una tensión interesante entre qué tipo de arte se podía mostrar, si la pintura tenía algún tipo de pertinencia para ese momento, y por supuesto, los cambios que había provocado la globalización no sólo en el sentido espacial sino también en el temporal, como presente, pasado y memoria. En efecto, parece que la globalización transformaba las maneras de concebir la misma estética y que generaba nuevas agencias. La periferia asumía de forma crítica la representación y la representatividad del arte en un contexto que se globalizaba rápidamente, al pensar las maneras en las cuales se podía representar su condición, más allá de exotismos. Esa situación se puede ver en las tres ediciones de la exposición, sobre todo en los continentes periféricos, en los que se hace referencia a la poscolonialidad, la identidad y las tradiciones locales. Sin embargo, es claro que para dichos autores una exhibición de esta naturaleza podría estar dislocada en el tiempo, aunque es evidente que encuentra un lugar en el espacio. Es en la Ciudad de México donde una muestra así puede hacer sentido porque es su misma tradición la que lo permite.

Por otro lado, respecto al continente europeo, las curadurías realizadas para la exposición siempre se refirieron al medio "sobre" el medio que se ponía en tensión con las mismas tradiciones pictóricas europeas y al parecer, lo que se

23. Mosquera, "América", 93-97.

24. Eder, "Apropiaciones", 22I.

25. Es fundamental entender que esa situación cambia en las siguientes dos ediciones del evento con las curadurías de Cuauhtémoc Medina, en 1999, y Víctor Zamudio Taylor, en 2000. En esas dos exhibiciones, y cada una a su manera, se reflexiona sobre la pertinencia de la pintura, su relación con el contexto mexicano y cómo es que se pueden cuestionar históricamente las maneras de enunciación del arte mexicano y la cultura nacional. 
alteraba era precisamente la condición de la pintura. Lo mismo sucedió en la segunda edición (1999) con el continente americano cuando el curador Bruce Ferguson, de Canadá, realizó una exhibición sobre la abstracción. Rosa Olivares, por su parte, propuso en la primera edición, una curaduría sobre la "pintura" y escribió un texto llamado "Aspectos, parciales, de la pintura europea. Después de la pintura”. Allí se expresaba el papel que había tenido en la historia del arte europeo y precisamente cuáles habían sido las nuevas relaciones con esa tradición. ${ }^{26} \mathrm{El}$ planteamiento de Olivares no sólo ubicaba la pintura como el centro de las reflexiones artísticas europeas sino del arte en general, incluso de varias formas de arte que podrían no tener relación. Pensar el parentesco de la foto y el video con la pintura, así como la condición pictórica de ambos no es únicamente desconocer la especificidad del medio, o incluso de los problemas que la noción de "imagen" ${ }^{27}$ puede implicar, sino que reduce la historia del arte del siglo xx a una especie de derivados pictóricos. Sin embargo, la centralidad de la pintura, histórica y geográficamente, y la manera en que el resto de "lugares" se ha subordinado a esa forma de centralidad, se convierte en la legitimidad incluyente del arte. Para Olivares, la pregunta por los orígenes del arte es fundamental, pero también la del futuro de la práctica. Al parecer, hay una precondición en la práctica artística, una especie de metafísica del arte manifiesta en esa narración. Así, la historia de la pintura (la historia de la especificidad del medio) queda vinculada con todo, literalmente hablando, desde el principio. Parece entonces que nada puede escapar de la pintura porque todo siempre ha sido pictórico, pero además porque todo lo que sigue será siempre pintura o estaría en un diálogo con ella.

En ese texto no hay discusión con la globalización ni con los asuntos de la identidad ni de la representación. Tampoco con las formas de circulación del arte ni de las maneras en que hay una distribución diferenciada entre los medios. La pintura, esencializada a luz y color, se pone como un foco del cual todo brota y del que nada puede escapar. Así, las tradiciones locales quedan subsumidas a ella, a su historia hegemónica, a su espacio abierto (pintura después de la pintura), pero siempre cerrado como vínculo. Es claro que el argumento de Olivares no representa todas las posturas sobre la pintura europea

26. Rosa Olivares, "Aspectos, parciales, de la pintura europea. Después de la pintura", en Cinco continentes y una ciudad: Salón Internacional de Pintura, 219-220.

27. Para referirse a este debate véase W.T.J. Mitchel, Picture Theory: Essays on Verbal and Visual Representation (Chicago y Londres: University of Chicago Press, 1994) (versión en español: Teoría de la imagen [Madrid: Akal, 2009]). 
del momento. Lo que me interesa es precisamente la postura inversa: todas las otras, las de los otros curadores que no son europeos o que no pertenecen a los centros artísticos y que hablan una y otra vez de cómo la globalización ha alterado las formas en las que se produce el arte y cómo es que de manera singular cada uno de los territorios también se ve alterado, dependiendo de cuál es la tradición pictórica con la que se identifican. Es claro que lo que dice Olivares es cierto, ya que para ella la pintura se circunscribe a una tradición occidental. Pero para el momento en que se llevó a cabo la exposición había que reconocer que comenzaba a existir un cambio importante en la manera en que se entendía el arte en todos los sentidos, la cual no se podía limitar a la lectura de la transformación del medio. La pregunta que estaba en el aire en las tres versiones de "Cinco continentes y una ciudad" era cómo y qué es lo que representa el arte y cómo es que nos podemos autodeterminar-autorrepresentar sin desconocer las relaciones de poder centro-periferia.

Las repuestas, como lo he intentado mostrar hasta ahora, son diversas y se asumen de diferente manera. Sin embargo, el intento de desmarcarse del arte de los años ochenta me parece significativo porque allí habían quedado asuntos pendientes que se interpretaron de formas muy parciales. La imposibilidad que tuvo la pintura de la década anterior de ser suficientemente representativa porque se la leyó como un exotismo o un arte vinculado al mercado, no permitió ver que allí había un carácter crítico, al menos para algunos. Esa postura se ha ido revisando en los últimos años. ${ }^{28}$ Sin embargo, me interesa señalar que la construcción en la que se puso a la pintura ochentera, sobre todo la mexicana, fue producto de un debate, particularmente internacional a finales de la década de los ochenta y durante los noventa, que nunca terminó de cerrarse y que generó más bien un relevo sobre otro tipo de arte minimal-objetualconceptual como en las obras de Gabriel Orozco (Xalapa, 1962), Francis Alÿs o Abraham Cruzvillegas (Ciudad de México, 1968).

Desde mi punto de vista hay que identificar, en primera instancia, cómo es que se configuró el discurso sobre la pintura de la década de los ochenta en

28. En 20Ir se presentó la exhibición “¿Neomexicanismos? Ficciones identitarias en el México de los ochenta”, curada por Josefa Ortega en el Museo de Arte Moderno de la Ciudad de México. De noviembre de 2010 a febrero de 201 s se presentó una exposición en el Instituto Cultural de México en San Antonio Texas, Estados Unidos, llamada "Neo-Mexicanism. A New Figuration: Mexican Art of the I980s", proyecto curatorial de la académica estadounidense Teresa Eckmann basado en su libro, Neo-Mexicanism: Mexican Figurative Painting and Patronage in the 1980's (Alburquerque: University of New Mexico Press, 20II). 
la tensión internacional entre Estados Unidos y México, porque allí radica el comienzo de la incorporación del arte mexicano a un diálogo internacional, que si bien intentaba mantener "lo mexicano" como un esencialismo fundamental, las posibles lecturas sobre el "otro" y "lo otro" ya estaban circunscritas en ese tipo de pintura que, sin embargo, se desacreditó durante la década siguiente. Cuando los artistas de la década de los noventa declaran que "no quieren ser artistas mexicanos sino sólo ser artistas" 29 es claro que no hay "neutralidad" en ser "sólo artistas" sino que quieren pertenecer a otra tradición que dialoga con la historia del arte hegemónica que construyeron los Estados Unidos desde la década de los sesenta, es decir, la conceptual-minimal-objetual ${ }^{30}$ y que ya se comenzaba a configurar como la hegemónica en la segunda mitad de la década de los noventa. Sin embargo, lo que me gustaría señalar es que el arte de los años ochenta ya era o "hacía" parte de esa dinámica globalizadora, o al menos es lo que comenzaba a anunciar. Sin eso no se hubiera podido dar siquiera el debate de cómo ser globales.

\section{América unida no es la misma América}

A principios de la década de los años noventa, en I99I, se inauguró el Museo de Arte Contemporáneo de Monterrey con una megaexposición llamada "Mito y magia en América: los ochenta", ${ }^{11}$ curada por Miguel Cervantes y Charles Merewether (fig. 2). "Mito y magia" intentaba trazar un panorama unificador del continente americano a partir del arte, específicamente de la pintura. Aunque la

29. Muchos artistas de la generación de los años noventa declaran con frecuencia que a ellos no les interesaba ser "artistas mexicanos", sino solamente "artistas". Para tener una referencia de ello véase Abraham Cruzvillegas, Round de sombra (Ciudad de México: Consejo Nacional para la Cultura y las Artes, 2006); Yoshua Okón y Alex Dorfsman, eds., La Panadería, 1994-2002 (Ciudad de México: Turner, 2005); Daniel Montero, El cubo de Rubik. Arte mexicano en los años 90 (Ciudad de México: RM, 20I4), entre otros.

30. Es claro que desde hace un tiempo se hace referencia a la idea de que la tradición del arte desde la década de los ańos cincuenta la enuncian básicamente los Estados Unidos. Para mayores detalles consúltese Serge Gilbaut, De cómo Nueva York robó la idea de arte moderno (Valencia: Tirant lo Blanch, 2007). La narración que realizan los críticos de la revista October en el libro Art since 1900 refuerza esa idea (Rosalind Krauss, Hal Foster, Yve-Alain Bois, Benjamin H.D. Buchloh y David Joselit, Art since I9oo [Nueva York: Thames and Hudson, 20I2]).

31. Miguel Cervantes y Charles Merewether, eds., Mito y magia en América: los ochenta (México: Marco, I99I). 
2. Portada del libro Mito y magia en América: los ochenta, vid. supra n. 3I.

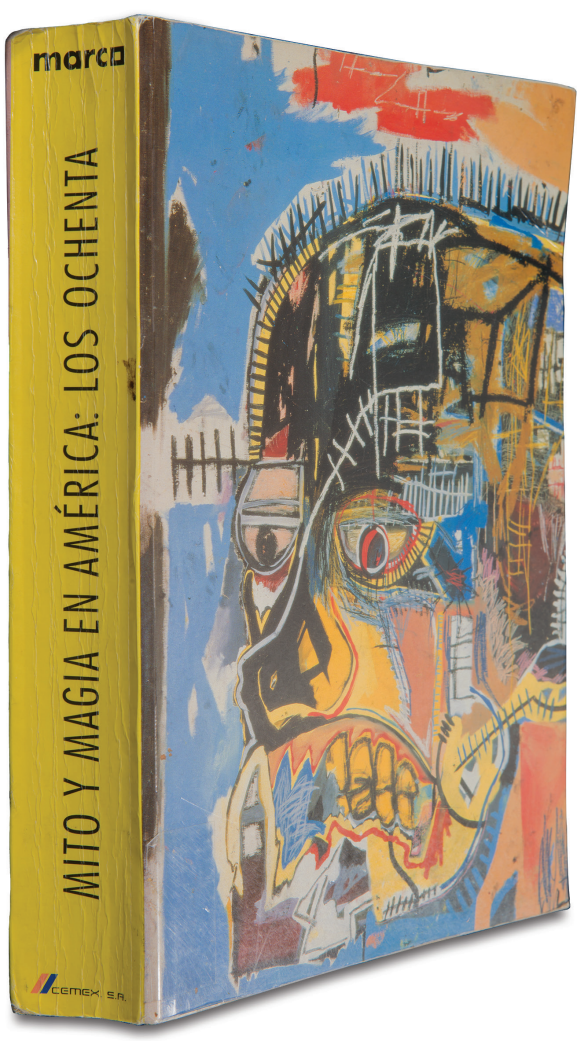

exposición mostraba a artistas de varios países americanos, ${ }^{32}$ había una predominancia de los artistas estadounidenses y mexicanos. ${ }^{33}$ Los criterios para realizar la exhibición estaban vinculados a cómo cada artista expresaba su localidad con relación al resto de países y a cómo se establecía una exaltación de la identidad,

32. Estaban representados Argentina, Bolivia, Brasil, Canadá, Chile, Colombia, Cuba, Ecuador, Estados Unidos, Guatemala, Haití, México, Perú, Puerto Rico, República Dominicana, Trinidad y Tobago, Venezuela.

33. Al respecto, Olivier Debroise escribió: "La amplitud de la sección mexicana, así como la fuerte presentación de los 'artistas de Monterrey, parece indicar que esta muestra sólo se realizó para ofrecerles un marco más amplio, mezclándolos y relacionándolos con pintores de otras latitudes, hasta cierto punto afines, y que han sido expuestos en Estados Unidos o en Francia." Olivier Debroise, "Es derroche de forma, color y pobreza imaginativa", El Norte, 2 de julio de I99I, 6. 
todo ello por medio de la pintura. En ese sentido, el museo se inauguraba con una exhibición internacional, en una ciudad periférica del arte en México, pero que intentaba estar a la vanguardia de las expresiones artísticas contemporáneas. ${ }^{34}$

Lo que me interesa destacar es que ésta fue tal vez una de las primeras exhibiciones internacionales realizada en México y la primera de esta naturaleza que se hizo en Monterrey, con pinturas en su totalidad, y que pretendía generar una unificación territorial a partir de un medio específico. Así, el mito y la magia estaban presentes en toda América, como elementos no sólo fundacionales sino también transformadores. No se explica, sin embargo, por qué sería sólo en la pintura donde se manifestarían ni por qué esos artistas podían ser referidos al mito y la magia de manera indistinta. En efecto, ese tipo de generalizaciones aplanó el discurso sobre los artistas presentes en la exhibición y en lugar de singularizarlos, los vinculó entre sí territorialmente y los esencializó con relación a su historia y a su futuro: los artistas que se mostraban allí, al parecer, no tenían un presente muy claro, o al menos ese argumento no se desarrolló a profundidad en el catálogo en ninguno de los textos. ${ }^{35}$

La presencia de la "pintura-pintura" en una exhibición se justificaba por un "temor" a la desaparición de la "pintura" (o de la pureza del medio) y por la intromisión de otro tipo de imágenes, tal vez menos pictóricas, que ya habían estado cuestionando la pertinencia de la pintura y su función cultural. En la descripción de la exposición en la página del museo se puede leer:

"Es la primera ocasión en que se hace una reflexión sobre arte de América, desde un país latinoamericano", dice Cervantes. "Realmente con esto Marco inaugura una forma de expresar y de ver la pintura del continente". "Creo que también tendrá una enorme repercusión en Europa como observadora de nuestro arte", señala el curador. Cervantes y Merewether seleccionaron la obra considerando las constantes de

34. Eduardo Ramírez hace una crítica interesante sobre la exhibición al decir: "Su exposición inaugural (la del Marco), 'Mito y magia en América: los ochenta' (I99I) es un intento de establecer un lazo de continuidad entre el neomexicanismo con la tendencia transcultural de Magiciens de la terre. Por otro lado, a fin de generarse fondos para la operación, Marco organizó una serie de subastas que no sólo seguían este intento de, a través de 'lo mágico', lo antropológico, insertar la estética neonacional en una internacional, sino que además se especulaba directamente sobre el valor en el mercado de algunas piezas." Eduardo Ramírez, El triunfo de la cultura: uso político y económico de la cultura en Monterrey (Monterrey: Fondo Editorial de Nuevo León, 2009), I29. Véase también www.marco.org.mx/index.pl?i=336

35. Los autores de los textos fueron Miguel Cervantes, Charles Merewether, Franceso Pellizzi, Alberto Ruy Sánchez, Peter Schjeldahl y Edward J. Sullivan. 
ejecución de la década de los ochenta, entre las que puede mencionarse el regreso a lo que se llama "pintura-pintura". [...] La "pintura-pintura" es un volver a los materiales y técnicas más tradicionales, como la pintura de caballete, óleos y acrílicos sobre tela (lino), sobre madera. La importancia de este retorno radica en que sucedió a pesar de que los pronósticos de los setenta decían que la pintura tradicional sería sustituida por una pintura hecha con recursos tecnológicos como fotocopias, computadoras. ${ }^{36}$

Resulta muy interesante pensar en un "regreso" de la pintura que "sucedió" a pesar de la tendencia de la década de los setenta por realizar "otra” pintura, hecha con recursos tecnológicos. Al parecer hay una escisión en la forma en la cual puede entenderse la pintura: ya sea por su fabricación o por su imagen. Una pintura hecha con pinceles, telas y bastidor es más pictórica que otras ( $s i$ es que a eso otro se le podría seguir llamando pintura), pero también, y de alguna manera, más esencial. Ese regreso es una introspección figurativa, de verse a sí mismo — a pesar de Europa—, pero de una forma mítica y mágica. La pintura hecha en América, y de alguna manera el arte americano, se asociaría con esas dos condiciones: entre más mítica y mágica más pintura-pintura. Pero también entre más material, más concreta, más fetiche.

El asunto, sin embargo, está vinculado a una serie de discrepancias interpretativas al interior del mismo catálogo, situación que se repite en muchos otros casos respecto a ese tipo de pintura. Lo que terminó sucediendo fue un boom de la visibilidad de esas obras en diferentes plataformas — primordialmente galerías, pero no sólo en ésta, como la exposición lo demuestra - tanto en Estados Unidos y México durante un breve periodo. Esto terminó por privilegiar un discurso esencialista, que a pesar de no ser el único venía bien para legitimar el ingreso de este arte a un circuito global y para repensar la localidad en otros términos "figurativos", es decir, una identificación del otro y hacia el otro. Todo esto tenía que ver con el uso que se le dio a esa pintura como elemento legitimador de la diferencia dentro y fuera de México. No es que el comercio excesivo de esas obras las "desactivara críticamente" 37 o incluso que la pintura no tuviera ningún sentido. Es que por un lado no era suficientemente autocrítica con el mismo sistema del arte, mientras por el otro era

36. "Mito y magia en América: los ochenta", Museo Marco, consultado el I2 de enero de 20I6, en www.marco.org. $\mathrm{mx} /$ index.pl?i=337\&ia=I\&ib=I99I\&ic=I39

37. Como se sabe, el neomexicanismo se asoció rápidamente al mercado del arte y eso se dio en detrimento de otras posibles lecturas críticas. Para mayor detalle véase Eckman, Neomexicanism. 
demasiado autorreferencial en el sentido en que el cliché se volvía en su contra, porque se convertía en la fuente y no en la referencia.

Por otra parte, ese tipo de arte parecía una pintura intemporal para algunos. La "pintura-pintura" no se vuelve tan sólo una especie de "ilusión-real" porque se remite a pasado-en-presente al utilizar, literalmente, imágenes que pertenecen al imaginario colectivo: las imágenes hacen parte de mi presente, de mi realidad, pero sé que son formas que me constituyen culturalmente, es decir, dentro del cuadro hay un reflejo de la identidad (del sujeto, de la cultura) que hace parte de la realidad, pero que no es "la" realidad, porque se ve alterada en la composición del cuadro mismo. Así, los cuadros forman parte de la cultura, pero conservan su estatus de arte en la medida en que una crítica a esa misma cultura es parte del cuadro. Sin embargo, parece que el cuadro fuera alterado por la cultura, sin ningún regreso de éste hacia afuera, más que un posible consumo de esa identidad. El tema es por tanto fundamental en dicha configuración, un tema figurativo. Esa situación se puede ver perfectamente en el texto del catálogo Mito y magia que escribió el curador Charles Merewether:

Mito y magia son indispensables del relato de la representación que se autoriza y sostiene a sí mismo. El poder atribuido a la magia es una fuerza de atracción y de repulsión entre los grupos sociales, una "cámara de espejos" que funde a las sociedades conquistadas y conquistadoras en una sola..$^{38}$

Y luego al referirse al kitsch y a la hibridación en la obra de Dulce María Núñez, el venezolano Carlos Zerpa comenta:

Al tiempo que transforman los roles de imágenes asumidas como iconos sagrados, introducen varios elementos de artificio, el kitsch y las formas híbridas de la cultura popular en las que se sostiene el poder de estas imágenes. En la obra de cada uno existe el reconocimiento de una interacción entre realidad y fantasía. Cuestiones como la autenticidad y la identidad son expuestas como temas imposibles de invenciones míticas. Así, el arte es una práctica de recuperación, reclamo y reinvención. ${ }^{39}$

Lo "popular" y lo "tradicional" en el arte contemporáneo no remarca la fuerza continua de la "mexicanidad", sino el surgimiento de una nueva "condición mexicana".

38. Charles Merewether, "Una gruesa fibra que atraviesa el cuerpo: transformación y renovación", en Mito y magia en América: los ochenta, XXX.

39. Merewether, "Una gruesa fibra", XLVI. 
La cultura indígena es rehecha, reinventada como una cultura de masas consumible: es naíf, es artesanal y kitsch. El mito de la "mexicanidad" se entrega a la cultura de masas y al mercado como un signo de la cultura popular. ${ }^{4 \circ}$

Y para finalizar,

Contemplar el arte americano desde fuera de Norteamérica es cambiar la historia de la modernidad del continente americano. Se convierte no sólo en un proceso de influencia o de apropiación, sino en una figura de transformación y de renovación multivocal, estratificada y siempre ambivalente. La obra que he considerado arranca el mito y la magia de las manos que convertirían lo no occidental en un fetiche primitivo y en un espectáculo deslumbrante de comercio, o de aquellos otros que sueñan con un retorno a los orígenes, buscando siempre escapar del desafío de la modernidad. ${ }^{4 \mathrm{I}}$

Como se puede ver, para Merewether el arte de América seleccionado en la exhibición no es un arte "del presente", es decir, no está hecho con elementos de imágenes producidas en el presente ni con situaciones que tengan que ver con ese contexto en particular sino con imágenes que vienen del pasado pero que se contemporanizan para crear un futuro, pero que deberían "afectar la paz" del presente desde el pasado. Por otro lado, no es difícil darse cuenta que para él esas pinturas se sitúan en una posición de ambigüedad que en lugar de concretar un sentido, lo dispersan. Ése sería, de hecho, su carácter político.

Ése fue tal vez uno de los asuntos que menos se abordó respecto a la crítica de ese tipo de pinturas. En efecto, el rápido consumo de ese arte no permitió cuestionar su propia naturaleza, como si todo fuera lo mismo e hiciera parte del mismo fenómeno. Es en ese sentido que la crítica en la década de los noventa lo consideraría un arte más acorde con la idea de "contexto", primero como un arte alternativo, luego como arte contemporáneo. Precisamente, el arte que se comenzó a producir en la década de los noventa hacía cuestionamientos desde la imagen y los objetos; un arte que era contemporáneo porque traía imágenes del pasado al presente para pensar en un posible futuro y al mismo tiempo pensaba en que su marco de referencia ya no podía seguir siendo la pintura como medio; un arte que ya no insertaba imágenes en un cuadro, sino que usaba objetos del contexto para producir; una forma de arte que

40. Merewether, "Una gruesa fibra”, XLVIII.

4I. Merewether, "Una guesa fibra", L-LI. 
ya no representaba sino hacía presentes (presentaba) situaciones locales. ${ }^{42}$ No es éste el espacio para hacer referencia a las discrepancias entre el arte producido en los ochenta y los noventa. Sin embargo, no está de más señalar que fue el arte que remitía al espacio y a los sujetos de otra manera el que terminó por entrar al mainstream artístico en los primeros años del siglo XxI. ${ }^{43}$

Ahora bien, la pretensión de unidad continental por similitud y técnica que se trataba de expresar en la exhibición de Monterrey, sólo era eso: una pretensión curatorial y de la crítica que asociaba de manera más bien libre una serie de obras hechas en diferentes contextos. Es claro que esa solicitud de la "diferencia" por parte de los centros era evidente ${ }^{44}$ y no se puede negar que

42. Sólo como ejemplos, en 199i en la Galería de Arte Contemporáneo de Benjamín Díaz, Abraham Cruzvillegas presentó una obra llamada Juanchito en Baviera, un pequeño muńeco hecho de mole negro que estaba recostado en una esquina. En 1997 Yoshua Okón y Miguel Calderón realizaron una obra en la que mostraban a propósito una serie de estéreos de carro apilados y un video en el cual se podía ver a un personaje rompiendo un vidrio de un auto para robar. La primera obra es un claro comentario a la raza en el país. La segunda se refiere al momento de inseguridad y de violencia que se vivía en la Ciudad de México en la década de los años noventa. Como se puede observar, ambas obras se realizaron con elementos locales y hacían comentarios particulares respecto a su contexto particular. Para mayores detalles véase Montero, El cubo de Rubik.

43. Como se sabe, muchas de estas obras producidas en los ańos noventa se comenzaron a exponer en diferentes espacios de Estados Unidos y Europa como por ejemplo en la exposición "Mexico City: an Exhibition about the Exchange Rate of Bodies and Values", en el P.S.I en Nueva York y en la Kunst-Werke de Berlín en 200I, y "México ahora, punto de partida” en Rif Gallery, (Ohio Arts Council), Columbus (Ohio) en 1997.

44. En 1991, Russell Ferguson apuntaba: "Cuando decimos marginal, debemos preguntar siempre ¿̨marginal a qué? Pero esta pregunta es difícil de responder. El lugar desde el cual el poder es ejercido es con frecuencia un lugar escondido. Cuando tratamos de señalarlo, el centro siempre parece estar en otro lugar. Aún así sabemos que este centro fantasmagórico, exclusivo como es, ejerce un innegable poder sobre todo el marco social de nuestra cultura, y sobre las formas en que pensamos sobre ello. Audre Lorde llama a este centro la norma mítica, definida como 'blanco, delgado, hombre, joven, heterosexual, cristiano y con seguridad financiera'. Aunque cada una de estas caracterizaciones trae consigo un peso diferente, su combinación describe un estatus con el que todos estamos familiarizados. Define los estándares tácticos desde los cuales los otros pueden ser declarados para desviarlos, y mientras el mito es perpetuado por aquellos a los cuales sirve a sus intereses, también puede ser internalizado por aquellos quienes son oprimidos por él. Esta estructura de la que no se ha hablado es rechazada por los autores de este libro. No se permiten a sí mismos definirse sólo con relación a otra cosa. Se sostienen en su propio suelo, y hablan desde ahí sin disculparse", en Russell Ferguson, "Invisible Center", en Out there. Marginalization and Contemporary Cultures, eds. Russell Ferguson, Martha Gever, Trinh T. Miah-ha y Cornel West (Nueva York: The MIt Press/The New Museum of Contemporary Art, 199I), 9. Es interesante notar cómo es que se entiende al otro en esta dinámica. 
había una moda por la pintura en ese momento. Pero tratar de asociar a todo el continente - que a pesar de tener una historia colonial similar, tiene una tradición artística y un referente diferente- a partir de la pintura parecía un despropósito.

Francesco Pellizzi lo expresó de manera muy puntual en su texto del catálogo al decir,

Lo que ha ocurrido últimamente, en los años ochenta, es que lo que fuera la vieja y habitual condición del Nuevo Mundo, en el sur y en el norte, se ha convertido en una característica tan extendida de la modernidad actual que América se encuentra en el verdadero corazón de esta forma universalmente fragmentada de conciencia e identidad, que produce la ilusión —y por ende la angustia — de estar al mismo tiempo "aquî" y "en cualquier parte" y también —a través de la repetición ilimitada— de estar en "diferentes épocas" en el "mismo lugar". 45

Así, para el autor hay una ilusión de simultaneidad de tiempo y lugares en la que América se encuentra como centro de la discusión. Así, el continente aparece como centrado y descentrado al mismo tiempo y el territorio americano como un lugar privilegiado para poder hacer ese tipo de apuntes visuales como la exposición "Mito y magia". Más adelante Pellizzi afirma que lo que está operando es una nueva forma no sólo de entender el arte y hacer arte sino que tiene que ver con el desarrollo mismo de los intercambios producidos por la modernidad. Pellizzi agrega que:

Hoy, en nuestro medio ambiente de imágenes universalmente mediadas la relación entre el "arte" y las "ideas" ha cambiado radicalmente, y las últimas han obtenido una aparente primicia sobre el primero: la vieja "manera de hacer" ha quedado relegada a un papel secundario en términos de lo que puede (y debe) hacerse o imitarse.

La transmisión de "formas artísticas" en éste y otros continentes es casi instantánea y simultánea, pero aún se caracteriza hoy, como en el pasado, por fuerzas direccionales y "apropiaciones recíprocas" que no son necesariamente simétricas. No es simplemente cuestión de jerarquías, de hegemonías culturales o del así llamado "imperialismo". [...] La modernidad supone cierto rechazo de las raíces específicas

45. Francesco Pellizzi, "La asamblea de los pájaros”, en Mito y magia en América: los ochenta, LIV. 
y bien localizadas; pero sólo al no negarlas de tajo su fuerza atávica es contrarrestada en diversos campos. ${ }^{46}$

Hoy día la transferencia de las formas artísticas puede ocurrir "centrípetamente" con un movimiento hacia lo interno, con origen en un área dada y en su pasado o "centrífugamente" yendo hacia lo extremo y lo ajeno, adoptando estilos diferentes. En el continente americano, la combinación de estas dos tendencias divergentes toma matices tan variados como sus propios habitantes, y el trabajo más significativo que se realiza actualmente resulta de un rápido flujo de imágenes e ideas (un movimiento "horizontal") que se intersecan con las capas "verticales" de la cultura regional.47

Como se puede ver en estos apartados, todo el texto de Pellizzi es muy complejo. La pregunta que lo articula es cómo se puede ser cosmopolita y a la vez tener una relación directa con el territorio que circunscribe la producción artística. La respuesta que ofrece Pellizzi tiene que ver con que llegar a ser moderno no se "alcanza" por un "avance" en las "formas" sino más bien por una tensión entre los tiempos y los espacios diferidos, pero que se manifiesta de maneras simultáneas en las obras por medio de capas.

El que esa exposición no hubiera sido posible antes pero sí en I99I, está relacionado con la manera en que se comenzaban a comportar las imágenes para ese momento en términos de flujo, de intercambio y de interpretación. Para Pellizzi hay una tensión liminar que explica los diferentes estilos, pero también la manera en la cual el ser moderno se expresa a partir de sus "formas" hacia adentro y hacia afuera en términos de espacio y también de tiempo. En ese sentido, no es que haya una unificación pareja y uniforme sino que depende de cómo es que se asimilan esas formas en cada uno de los territorios. Así, lo nuevo y lo viejo, como forma y estilo, no necesariamente estarían "adelante", sino que podrían encontrarse "atrás", en otros momentos históricos, generando una tensión entre arte y artesanía. ${ }^{48}$

Es curioso, sin embargo, que Pellizzi se refiera sólo a las maneras en que se produce este tipo de arte y no a la forma en la que se muestra. De hecho, no desarrolla la idea de la posibilidad de pensar en el lugar de exhibición de estas obras ni cómo es que pueden leerse contextualmente en la circulación

46. Pellizzi, "La asamblea de los pájaros", LVIII.

47. Pellizzi, "La asamblea de los pájaros", LX.

48. Para Pellizzi hay una tensión siempre presente en la pintura en la relación manual-intelectual que convoca a su vez a una tensión entre artesanía y arte. Véase Pellizzi, "La asamblea de los pájaros". 
de las "imágenes" y de las "obras". Lo que me parece significativo es que se refiera al cambio que está sufriendo la ciudad de Nueva York por artistas de otros lugares que han llegado a producir allí y cómo es que esa situación ha modificado el arte local, pero no aborda cómo es que esa relación de poder tensa las maneras en que se enuncia el arte.

Sin embargo, y a pesar de que intenta romper las lecturas esencialistas y completamente localizadas de la pintura de los ochenta, el texto no explica el porqué de la exclusividad pictórica de la exposición. Tal vez se podría inferir a partir del mismo texto, que es allí, en la pintura como medio, donde es posible identificar una relación temporal y espacial específica, que se puede ver en el formato del cuadro. En ese espacio se condensarían todas las relaciones y los flujos de imágenes del pasado y del presente, y también las relaciones entre la idea y la materia. Cuando Pellizzi afirma que "la modernidad supone cierto rechazo de las raíces específicas y bien localizadas; pero sólo al no negarlas de tajo — de hecho poniéndolas por delante de la conciencia y de la práctica artísticas, y después reabsorbiéndolas completamente en lenguajes nuevossu fuerza atávica es contrarrestada en diversos campos", ${ }^{49}$ se refiere al mismo tiempo al carácter "primitivista" de algunas de esas imágenes, pero también al oficio de pintar artesanal como un momento premoderno del arte. Aunque sólo asumiendo ese tipo de imágenes mediante la pintura y no negándolas, es como podría haber algún tipo de relación con la modernidad: somos modernos porque podemos pintar imágenes que nos pertenecen y en la medida en la cual las asumimos como propias, pero que potencialmente pueden ser de alguien más.

Por supuesto que todo el argumento de Pellizzi sólo funcionó de esa manera en la crítica y en el formato de esa exposición. La idea de la tensión entre el pasado y el presente se convirtió en un nuevo esencialismo porque así se terminó "vendiendo", asunto con el que muchos críticos estaban en desacuerdo..$^{\circ}$ Sin embargo, me parece importante mostrar que la crítica que hacía el autor a este tipo de pinturas se pensaba como manera de interacción de las imágenes que al mismo tiempo que dialogaban con otras, conservaban algo que las hacía pertenecer a un lugar a partir de su tradición; unas imágenes que relacionadas con un imaginario local, y en tanto tal, pueden incorporarse al flujo

49. Pellizzi, "La asamblea de los pájaros", LVIII.

50. En la década de los ańos noventa hubo ataques críticos muy puntuales a la pintura de la década de los ańos ochenta. Sólo habría que considerar muchos de los textos que escribió Benjamin Buchloh en Estados Unidos y por supuesto la crítica de arte latinoamericano de Gerardo Mosquera, Nelly Richard y Mari Carmen Ramírez, entre muchos otros. 
de imágenes de otras maneras en juegos de poder y adquirir un papel que ya no sería completamente subalterno.

Tal vez ése era el conflicto mayor de esta exposición: quería afanosamente generar un nuevo canon territorial a partir del flujo y no pudo pensar en que los otros aparatos iban a neutralizar los posibles diálogos que este tipo de pintura pudiera tener con otros lugares, así todos estuvieran pintando "lo mismo". Era una pintura demasiado "local" y autorreferencial como para pensar en una unificación de algún tipo. Además, era ingenuo considerar que el arte estadounidense, luego de un proceso complejo de exclusión del arte latinoamericano y de sus fronteras, iba a incluir nuevamente ese tipo de discursos continentales. ${ }^{\text {II }}$ Más que una diferencia anclada en el pasado, era necesario mantener una diferencia que circulara pero que tuviera un código compartido que subyacía desde tradiciones foráneas ${ }^{2}$ ancladas en las "tradiciones" estadounidenses de los sesenta y setenta.

El texto de Pellizzi, así como los de los autores estadounidenses en el catálogo (Charles Merewether, Peter Schjeldahl, Edward Sullivan), contrasta fuertemente con los de los mexicanos Miguel Cervantes, ${ }^{33}$ cocurador de la exposición, y Alberto Ruy Sánchez. ${ }^{54}$ Los dos argumentan a favor de una continuidad en las tradiciones del arte mexicano por vía de la pintura y que son más o menos grandiosas, porque siguen esa tradición. Así, la pintura se eleva como conti-

5I. El mismo Pellizzi hace una referencia interesante al respecto para mostrar la tensión con el arte mexicano y el arte estadounidense, partiendo de una absorción parcial del gesto expresivo de este último para luego generar una diferencia a partir de la individualidad. "Desde luego que existe una ligereza y libertad en el gesto, particularmente en Pollock, pero también mucho de aquello que le acompañó y le siguió, que le debe algo esencial — desde mi punto de vista— a los muralistas mexicanos. Pero la influencia, o mejor dicho el intercambio al que me refiero no es precisamente formal, aunque sea factible expresarlo en términos formales: bajo la experiencia de una cuestión 'patriótica' o ideológica, se encubre en realidad la afirmación de una nueva y más radical versión del 'individualismo'. Lo que quiero decir es que algo a la vez un tanto 'loco' y 'naíf', se introdujo en la corriente principal del arte y esto también se debió a ese acto deliberado de empatía que Herder percibía como fuente de la única posibilidad de comprensión histórica e intelectual entre individuos pertenecientes a comunidades distintas". Pellizzi, "La asamblea de los pájaros", LXIX. Un argumento de la exclusión del arte latinoamericano del estadounidense también se puede ver en Cuauhtémoc Medina, "Delay and arrivals", Curare 27 (2006): I08-II7.

52. Véase Stuart Hall, “¿Quién necesita 'identidad'?”, en Cuestiones de identidad cultural, Stuart Hall y Paul du Gay, comps. (Buenos Aires y Madrid: Amorrortu, 2003), I3-39.

53. Miguel Cervantes, "Introducción", en Mito y magia en América: los ochenta, XXV-XXVII.

54. Alberto Ruy Sánchez, "Una nueva geografía imaginaria", en Mito y magia en América: los ochenta, LXXXI-LXXXIX. 
nuidad del arte. 55 De forma singular, la representación de los textos de mexi$\operatorname{canos}^{56}$ en el catálogo es la que mejor muestra ese afán por ser cada vez más "nosotros". Esos textos no ponen en relación ni las imágenes que se muestran ni se detienen a pensar en la misma función ideológica del medio. En ese sentido, no se podía esperar mucho valor local de esas obras, por más que se las exaltara. El que semejante postura no entrara en un diálogo crítico más amplio impidió una discusión sobre la pertinencia de ese tipo de pinturas porque ya se daba por hecho. Curiosamente, en donde hubo más discrepancias fue en Estados Unidos con lecturas diferenciadas de ese fenómeno, provocado por la necesidad del arte mexicano por ser "él mismo".

\section{La pregunta por la pintura mexicana en Estados Unidos}

La manera en que se entendió la pintura producida en los años ochenta en México, en Estados Unidos estuvo marcada principalmente por un discurso que se centraba en la exhibición de la diferencia y no tanto en una relación unificadora continental. En el país del norte, las maneras de entender esa forma de pintura tenían que ver con "el otro" que pertenece a un territorio y a una historia específicos. Sin embargo, al igual que en la exposición "Mito y magia: los ochenta", tanto la crítica local como la que venía especialmente de México tenían diferentes posturas respecto a cómo leer esas obras y, por supuesto, cuál podía ser su sentido. Es importante decir que muchas de las exhibiciones fueron itinerantes así que tener una visión general de esas lecturas es muy difícil. Sin embargo, hacer notar la itinerancia es fundamental: al parecer era importante generar una visualidad plural considerando las diferentes maneras de entender el arte en Estados Unidos, en particular en las costas este (Nueva York) y oeste

55. Alberto Ruy Sánchez apunta por ejemplo que "hay momentos privilegiados en la historia del arte, en los que la creación toma de pronto un ritmo más intenso, surgen formas audaces y artistas que rompen las fronteras estéticas en las que nacieron. La década de los ochenta en el continente americano es uno de esos momentos", Alberto Ruy Sánchez, "Una nueva geografía imaginaria”, LXXXI.

56. Es interesante notar cómo es que estas posturas se diferencian significativamente de las primeras críticas que aparecen en los periódicos de finales de los ochenta que, por cierto, no están incluidas en el catálogo a pesar de ser de personas importantes en el mundo del arte local. Véase, por ejemplo, Teresa del Conde, "Nuevos mexicanismos", en "Sábado", suplemento de Unomasuno, 25 de abril de 1987, o Jorge Alberto Manrique, "Desfiguros", La Jornada, I6 de enero de 1990. 
(California) y en el sur (Texas), que también tenía que ver con las pretensiones de descentramiento del mercado de esas obras. ${ }^{57}$

Por el momento me interesa mostrar un par de lecturas de la pintura mexicana desde Estados Unidos, en particular de la exposición "Aspects of Contemporary Mexican Painting" (fig. 3), para evidenciar que la crítica de arte en ese país no se recibía de manera uniforme; que no había un consenso en la comprensión de esa pintura, que se tensaba por la tradición norteamericana desde Estados Unidos. En Nueva York la crítica, un poco más indulgente con este tipo de obras, pretendía entender, sobre todo desde la diferencia y del "otro" (de su historia particular), qué pasaba con el arte mexicano. Como se puede leer en el artículo de Michael Brenson "Where the Physical and the Spiritual Both Meld and Clash", publicado en el New York Times:

Cuando hay un intento de introducir en un país el arte de otro, los resultados inevitablemente serán una mezcla. Y mezclar las exhibiciones actuales de arte contemporáneo mexicano en la ciudad de Nueva York sin duda lo es. [...] A partir de las dos mejores exposiciones - "Aspects of Contemporary Mexican Painting"” y "Forces of History, Symbols of Desire" - es claro que la obra narrativa de gran alcance didáctico de "Los Tres Grandes", [...] no es la principal influencia. También está claro a partir de estas exhibiciones, que muy poca pintura mexicana contemporánea relevante es abstracta. Una inspiración para los artistas más jóvenes es Rufino Tamayo, que fue severamente criticado en la década de 1930 porque no siguió la línea ideológica de artistas como Rivera y Siqueiros. Su independencia ahora se percibe como una fortaleza. [...] La otra importante fuente de inspiración para el arte mexicano contemporáneo en Nueva York es Frida Kahlo. [...] [A partir de aquí] es posible hacer algunas generalizaciones sobre el arte mexicano contemporáneo. No hay ortodoxia estilística o ideológica. El cuerpo como fuente de placer y un objeto de sufrimiento y dolor es uno de los temas. La máscara es otro. En algunos de los trabajos más interesantes, el amor por el arte mexicano antiguo se combina con un sentido del peso opresivo de la tradición. $\mathrm{Al}$ igual que en el arte americano contemporáneo, la identidad personal, artística y cultural es una gran preocupación. ${ }^{58}$

57. Algunas de esas exhibiciones que se hicieron en Estados Unidos son "El corazón sangrante", "Aspects of Contemporary Mexican Painting", y por supuesto el "Parallel Project", entre otras. Es claro que el Parallel Project, en el que participaban la Galería de Arte Mexicano (GAM), omr y la de Arte Actual Mexicano que acompañaban la exhibición "Mexico a Work of Art" buscaba abrir mercado a las obras neomexicanistas en diferentes partes de Estados Unidos, no sólo en Nueva York.

58. Michael Brenson, "Where the Physical and the Spiritual Both Meld and Clash", The New York Times, 5 de octubre de 1990, consultado el 3 de febrero de 20I6, en www.nytimes. 
Es interesante pensar en la relación que establece el autor entre los dos países, en la que la cultura podría llevarse de un lugar a otro para trazar un panorama. La frase con la cual comienza la reseña es muy significativa porque en efecto lo que se intentaba hacer era "meter" el arte de un lugar a otro como una representación nacional muy particular. ${ }^{59}$ Lo que me interesa es que para Brenson las muestras que ocurrieron en 1990 son "informativas" respecto del arte contemporáneo de ese momento, pero con otra tradición que no es ya la del muralismo sino la de la exaltación de la subjetividad y de la localía: en lugar de Diego Rivera son Frida y Tamayo (su mujer y su antagonista artístico), que no pertenecen a una tradición abiertamente político-militante, sino más bien a una nueva configuración de la identidad a partir de sus temas y sus colores. Un arte independiente, más puro y libre, que exalta la subjetividad. La identificación de lo mexicano deja de estar vinculada con el proceso revolucionario para relacionarse con otra, tal vez mucho más ancestral y pura. Sin embargo, se encuentra afinidad con el arte norteamericano en el sentido de una búsqueda de la identidad, un argumento que ya he señalado respecto a la exhibición "Mito y magia".

Por otro lado, algunas de las críticas que se hicieron en Los Ángeles tienen otro tono y ven el arte mexicano de los años ochenta poco interesante. Para Christopher Knight, crítico de Los Angeles Times, esa pintura está abiertamente vinculada con el arte europeo, en particular con la escuela de París. Como lo afirma Knight en este pasaje que vale la pena citar extensamente:

El principal aspecto de la pintura mexicana contemporánea es que se sigue tratando de inyectar una chispa de vida en el cuerpo helado de la escuela de París. En su mayor parte, por desgracia, el cuerpo frankensteniano simplemente yace allí, negándose a levantarse y bailar. [...] "Aspects of Contemporary Painting in Mexico" quiere sugerir una herencia específica, que comienza con el cambio de generación con Tamayo, pasa la batuta a [Rodolfo] Morales y, por último, deja el espacio a los jóvenes de la posguerra.

Un compromiso con las tradiciones del modernismo europeo está en todas partes en la exhibición que se presenta actualmente en Santa Mónica: las pinturas de

com/1990/ro/os/arts/review-art-where-the-physical-and-the-spiritual-both-meld-and-clash. html?pagewanted $=\mathrm{I}$ (trad. del autor).

59. La exhibición "Mexico: a Work of Art" era precisamente eso: establecer una relación cultural con Estados Unidos desde México llevando una serie de manifestaciones culturales locales a otro territorio. 
Alejandro Colunga, Arturo Marty, Ismael Vargas, Dulce María Núñez, Rocío Maldonado y Georgina Quintana son reverberaciones estilísticas de Francis Bacon, Jean Dubuffet, Oskar Kokoschka, varios fauvistas y otros maestros modernos. Lo más importante es el énfasis expresionista en la relación del artista con la pintura, en lugar de la relación de la pintura con el mundo.

Algunos de los artistas — Núñez, Maldonado y Julio Galán— hurgan en la historia del estilo, escogen y eligen lo que necesitan de una manera ostensiblemente apropiacionista, con lo que colindan elementos aparentemente contradictorios. Que lo hagan en la pintura, que su trabajo (como el de todos los demás) sea figurativo, y que la muestra recopile el arte de la década de i980 (la fecha más temprana es I982), todo conspira para darle un giro curatorialmente no declarado pero evidente: a pesar de que el término nunca se utiliza, el neoexpresionismo es el pegamento que mantiene juntos en la exposición los trabajos dispares. ${ }^{60}$

Aunque no las desarrolla a profundidad, son muy sugerentes dos de las afirmaciones que Knight propone en su crítica. En primer lugar la relación que tiene la pintura expresionista con la pintura en sí misma y no su relación con el mundo. En segundo lugar, el intento por revivir la pintura mexicana después del "hundimiento" que le proporcionó el expresionismo abstracto al muralismo. En ese sentido, la pintura de la década de los ochenta sería un intento por volver a darle un lugar al arte mexicano en la historia del arte vinculada con Europa como un derivado contemporáneo. Sin embargo, ese derivado no funciona del todo y las obras son un "cuerpo frankensteniano que no levanta". La visión de Knight es singular porque no reconoce en esas obras un rompimiento con la historia del arte mexicano (como lo hace Sullivan en el catálogo de la exposición) (fig. 3), ${ }^{61}$ sino más bien una continuidad en relación con la tradición de la pintura, pero por otra vía, más europea que americana, más figurativa-expresionista que política. Knight sigue su narración diciendo que:

El neoexpresionismo fue el success d'estime de la pintura en los ochenta. Ciertamente, el neoexpresionismo mexicano ha brotado de una historia bastante diferente de la que guió a sus homólogos alemanes, italianos y americanos. Edward Sullivan insiste

6o. Christopher Knight, "Mexico's Old-Style Contemporaries," Los Angeles Times, II de diciembre de I99I, consultado el 3 de febrero de 20I6, en http://articles.latimes.com/I99I-I2-II/ entertainment/ca-37_I_contemporary-mexican-painting (trad. del autor).

6I. Edward Sullivan, Aspects of Contemporary Mexican Painting (Nueva York: Americas Society, 1990). 
3. Portada del libro de Edward Sullivan, Aspects of Contemporary Mexican Painting (Nueva York: Americas Society, 1990).

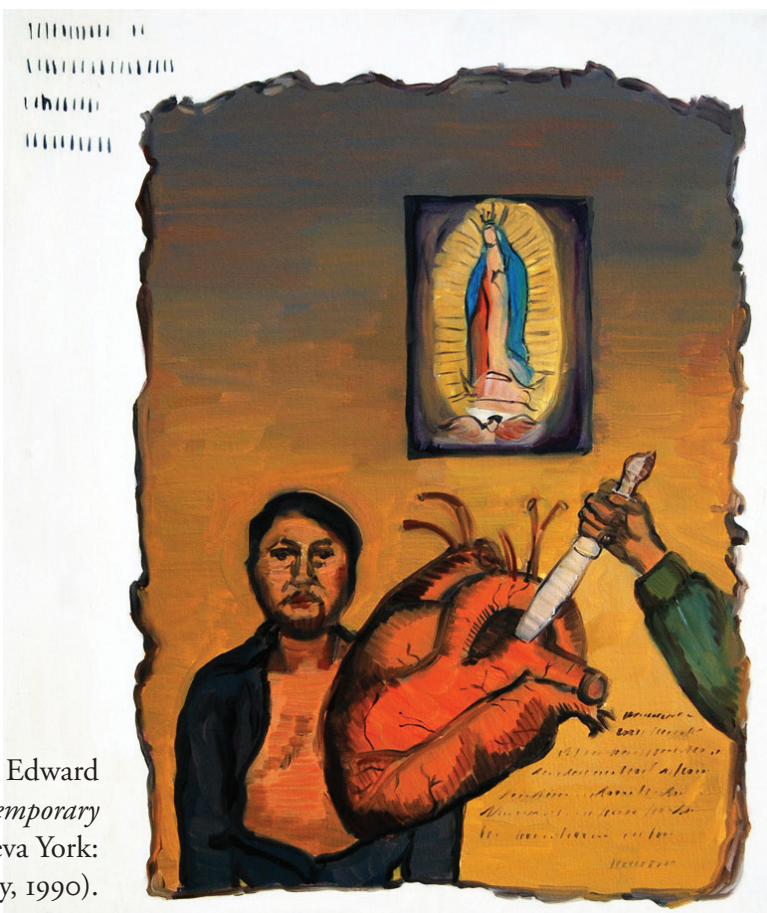

en el catálogo de la exposición que estas pinturas marcan una ruptura repentina y decisiva con el pasado; también dice que estos pintores no son conscientes de la historia cultural de su nación. En cierto modo, se podría decir que lo que renace en estos trabajos es una cepa particular de arte mexicano que ha sido largamente reprimida.

La Escuela Mexicana — la llamada "Escuela Mexicana” de la pintura de caballete modernista que floreció entre los años 1920 y la década de I940, y que en realidad es simplemente una rama derivada de la escuela internacionalmente dominante de París-, hacía tiempo que había sido eclipsada por la pintura mural política y mordaz de Diego Rivera, José Clemente Orozco y David Alfaro Siqueiros. Cuando sus murales demostraron ser influyentes en la formación del expresionismo abstracto americano, se selló el destino de la Escuela Mexicana. Desapareció de la vista. "Aspects of Contemporary Painting in Mexico" significa revivir el género desaparecido como una fuente potente. ${ }^{62}$

62. Christopher Knight, "Mexico's Old-Style Contemporaries", Los Angeles Times, II de diciembre de I99I, consultado el 3 de febrero de 20I6, en http://articles.latimes.com/I99I-I2-II/ entertainment/ca-37_I_contemporary-mexican-painting (trad. del autor). 
No obstante, y como se puede ver en la frase final del texto ésa no es la vía para hacer referencia al arte mexicano reciente porque los intentos por revivir un medio como la pintura son infructuosos, precisamente porque el medio ya es un "difunto". Knight prefiere otro tipo de obras, como las que se expusieron en el Art Center College of Design ese mismo año en la exposición "The Perennial Illusion of a Vulnerable Principle: Another Mexican Art” curada por Guillermo Santamarina y María Guerra. ${ }^{63}$ Ese "otro" arte mexicano que se mostraba en esa exposición tenía que ver con otra tradición, la de un arte mucho más conceptual de instalaciones hechas in situ y que se diferenciaba radicalmente de las pinturas que se promocionaban como continuidad de la tradición de Tamayo/Frida/Nieto, pero también de la de los muralistas. Con el contrapunto de "The Perennial Illusion", Knight puede considerar que, en efecto, la exposición "Mexico: a Work of Art" ofrece un panorama muy parcializado del arte que se produce en el país y que todo el evento celebratorio no es más que una estrategia institucional para promover cierto tipo de identidad "pura". Efectivamente las obras que se presentaron en Pasadena, como Knight lo indica, tienen que ver más con la posibilidad de pensar en las relaciones de poder e internacionales que existen entre México y Estados Unidos y no en un solo desplazamiento del "meter" una cultura a la otra, como supone el modelo que describe Brenson en el artículo del New York Times.

Las posiciones diferenciadas entre críticos, uno en Nueva York y el otro en Los Ángeles, hacen imposible generar un consenso del "origen" de este tipo de arte, más allá de la referencia a esa "otra" tradición, que no es la del muralismo. No obstante que esa "tendencia" se adoptó para poder "vender" la cultura mexicana en Estados Unidos — para vender al país previo a la entrada en vigencia del TLCAN, como lo afirma Shifra Goldman— ${ }^{64}$ sí se tenía claro que había una "despolitización" del arte mexicano a favor de una relación más inti-

63. En la exposición se presentaron Carlos Aguirre, Agustín González Garza, Silvia Gruner, Marcos Kurtycz, Francisco Castro Leñero, Gabriel Orozco, Rubén Ortiz Torres, Juan Manuel Toledo y Diego Toledo. Véase una crítica a esta muestra del mismo Christopher Knight, "Cover Story”: “Perennial Illusion' Fills In Some Modern Gaps Left by 'Splendors”, Los Angeles Times, 29 de septiembre de I99I, consultado el 3 de febrero de 20I6, en http://articles.latimes.com/I99I09-29/entertainment/ca-483I_I_exhibition.

64. Véase en particular los artículos de Shifra Goldman, "Reescribir la historia del arte mexicano: economía política de la cultura contemporánea” y "Esplendores metropolitanos", en Shifra Goldman, Perspectivas artísticas del continente americano, trad. Esther Cimet S. (Ciudad de México: Universidad Autónoma de la Ciudad de México/Instituto Nacional de Bellas Artes y LiteraturaCentro Nacional de las Artes, 2008), 373-396 y 453-462, respectivamente. 
mista con las imágenes del cuerpo y de la "identidad". No es casualidad que la idea de la máscara en las lecturas críticas fuera tan recurrente. Y sin embargo nunca se habló de las políticas de la imagen del cuerpo en la pintura, por ejemplo. La ansiedad crítica estaba dirigida más bien a saber de dónde venían esas imágenes y cuál era su tradición porque ésa era la que se quería instalar en ese presente, ya fuera ruptura o continuidad, crítica política o mercancía. Y por supuesto, vincularla con alguna tradición pictórica. Lo que es claro es que las lecturas estaban parcializadas y no se hacía explícita una condición "mixta" de las obras. Había entonces una pregunta por el arquetipo que las constituía. Esas maneras de ver el asunto terminaron de convertir a la pintura mexicana de la década de los ochenta en un estereotipo y propiciaron una única forma de ver(la).

Así, la manera como se recibía esa pintura en Estados Unidos da cuenta del éxito relativo que tuvieron ese tipo de obras, más allá de la lectura que se privilegie. Era un arte que estaba en diálogo con el adentro y el afuera del país en relaciones que pasaban por Europa, Estados Unidos, las "tradiciones pictóricas mexicanas" (todo lo que eso implica en ese contexto), pero también con el presente del país, no tanto con relación a su situación como crisis económica, política y social, ${ }^{65}$ por ejemplo, sino más bien con el reconocimiento de las formas en que los sujetos se constituían por las imágenes, y, a su vez, eran representados por ellas.

\section{Re-considerar la pintura más allá de sí misma}

Desde finales de la década de los noventa mucha de la pintura mexicana de los ochenta dejó de exponerse en los centros de exhibición mainstream, situación que produjo una nueva consideración sobre la pintura y su pertinencia como medio para esta época, es decir, y en pocas palabras, la pregunta de si esa pintura (e incluso la pintura en general) sería lo suficientemente contemporánea. La situación hacia finales de la década de los noventa para el contexto mexicano es que no. Si se ve la transformación de las exhibiciones mexicanas de

65. Muy pocas pinturas neomexicanas se refirieron directamente a las crisis económicas o sociales en sus imágenes. Las pinturas de 1985 de Rubén Ortiz-Torres, Lo que el viento le hizo a Juárez, El fin del modernismo y La persistencia de la memoria, tres pinturas sobre el terremoto de 1985 en la Ciudad de México, pueden ser ejemplares. 
"Cinco continentes y una ciudad" se puede constatar que, al menos en la Ciudad de México, la pintura ya no era suficientemente representativa de la escena artística local: en 1998, Eder exhibió todavía a muchos de los pintores de la década de los ochenta; en 1999, Medina convocó a artistas de una generación más joven que entre sus prácticas conservaban el formato bidimensional aunque su discurso curatorial ya ponía en crisis la relación entre pintura, Estado, salón, historia, tradición, entre otras cosas; Víctor Zamudio-Taylor en 2000 ya no expone "pinturas" y usa un motivo de la pintura tradicional, el paisaje, para problematizar la relación entre el arte y la ciudad.

Así, se puede afirmar que no sólo han existido diferentes maneras de pensar la pintura en tiempos recientes sino que, en el fondo, lo que se ha cuestionado es la pertinencia de ciertos medios artísticos. O para ser mucho más radicales, lo que está en duda es la misma especificidad del medio, asunto que ha tenido un proceso particular, tensado por las maneras de producir arte, pero también a partir de la crítica y la curaduría. A finales de la década de los ochenta y comienzos de los noventa la crítica leía la pintura como si fuera encarnación y representación de algo que está a medio camino entre la presencia y la ausencia. Los cuadros muestran partes de lo mexicano, de la subjetividad del artista, de la tradición de la pintura local-foránea, y todo eso se encuentra en ese formato específico, en ese medio en particular. En ese sentido la pintura es una especie de contenedor (es una superficie siempre ideológicamente cargada) que se puede llenar de nación, de historia, de subjetividad... En efecto, ése es el resultado de un pensamiento que cree que entre más "directo" es el medio en la relación que se da entre el artista y la materia, es mucho más significativo porque no habría ya un aplazamiento del sentido y no se diferiría la experiencia. Que el medio seleccionado para la exposición "Mito y magia” fuera la pintura no es una casualidad porque aparece a la vez como un medio fundacional y alquímico. Por medio del ejercicio de la pintura se ponen en juego la historia (como oficial) y la memoria (como subjetividad) y a la vez una transformación efectiva de la materia en forma (pintura figurativa). ${ }^{66}$

Por otro lado, durante y a finales de los años noventa, con artistas de otra generación —como se puede ver en particular con la exposición de ZamudioTaylor-, el asunto se vio completamente rebasado. La pintura ya no era suficientemente representativa ni del contexto ni de los sujetos que lo habitan. De Heaven y Londres: Yale University Press, 1983). 
hecho, el giro se daba más bien desde la noción de objeto escultórico, en particular con los conceptos de Joseph Beuys (I92I-I986). ${ }^{67} \mathrm{Si}$ la premisa ya no era cómo es que se representa el sujeto a sí mismo, o a su país, o a su historia, sino más bien cómo es que éste es constituido por diferentes factores - económicos, sociales, históricos, entre otros- que ya no son fijos, ni espacial ni temporalmente, la pintura resultaba un medio que ya no era suficiente, no porque careciera de sentido, sino más bien por lo que había representado (ideológicamente) para el país hasta esa década, ${ }^{68}$ es decir, una forma verdadera de arte, un medio vinculado con un compromiso político e incluso su patrocinio incondicional por parte del Estado. Así, para finales de la década de los noventa el distanciamiento de la pintura no se da sólo en las limitaciones del medio sino también por una sobrecodificación del mismo y su uso por parte del Estado (como identidad) y del mercado (como mercancía).

Ahora bien, cuál es entonces el estatus de la pintura hoy, luego de estas consideraciones históricas por parte de la crítica local y foránea. La respuesta que puedo ofrecer es parcial. El texto curatorial de Medina respecto a la exposición de Alÿs es un buen punto de partida. Para el curador, la pintura en ese caso no es el centro de la obra sino que hace parte de un proyecto mucho más grande. En ese sentido no sería un medio privilegiado sino uno más con relación a una narrativa más amplia. El lugar ambiguo donde coloca a la pintura en su relato - "las pinturas son un proceso paralelo de pensamiento que ocurre cuando el artista imagina, planea o reflexiona sobre la creación de alguno de sus proyectos. Las pinturas de Alÿs son a la vez autónomas y accesorias al proyecto que las emite. Estos cuadros son simultáneamente la memoria y boceto de las ideas que acompañan las obras" - la transforma en el centro de atención; así como la obra The Cut se convierte en el centro de la exhibición al cortar una pintura en dos partes. Con el regreso del discurso "sobre" la pintura, y por mucho que se quiera descentrar, la atención se desvía inmediatamente sobre ese medio.

67. Es importante señalar que la referencia a la escultura hacía alusión directa a Beuys que era un artista muy influyente para la generación de los noventa. Sólo hay que recordar la exposición "A propósito, I4 obras en torno a Joseph Beuys", realizada en abril de 1989 en el Museo del Exconvento del Desierto de los Leones. Es interesante señalar la exposición "Escultura Social: A New Generation of Art from Mexico City", llevada a cabo en el Museo de Arte Contemporáneo de Chicago en 2007, la cual hace referencia de nuevo a las ideas de Beuys como algo importante para esa generación, incluso el mismo título de la muestra lo indica.

68. Cuauhtémoc Medina ya había planteado un argumento similar en su texto "Mexican Strategies. Rarefied Painting", Flash Art (enero-febrero, 2000): 76-78. 
En la exhibición eso quedaba claro porque todos los proyectos estaban acompañados de pinturas de pequeño formato. Así, la pintura se vuelve central siendo periférica al filtrarse en forma de aporía en ese discurso.

¿Qué sucede entonces con la pintura contemporánea después de sus mal llamadas crisis ${ }^{69}$ y luego de que la noción de imagen desplazara incluso cualquier especificidad de la pintura? Evidentemente la pintura puede considerarse una imagen. Sin embargo, creo que no es una imagen más por la manera en que el concepto de arte se construyó a lo largo de la historia a partir de ella. ${ }^{70}$ Además, es muy difícil trazar un panorama general sobre el estatus de la pintura en México no sólo por su diversidad sino porque, en algunos lugares, es un medio que sigue siendo privilegiado como en Monterrey y Oaxaca, y trae consigo nuevas luchas simbólicas particulares.

De lo que sí se puede estar seguro es que cada vez más hay un recambio de imágenes desde y hacia la pintura provocado por procesos de digitalización y por la masificación del internet. En la red se juega en gran medida con las imágenes de la historia del arte, pero también entran al cuadro imágenes que circulan, ya sea para hacer un comentario preciso sobre la misma red o para señalar la relación con la información y cómo es que las imágenes constituyen

69. Yve-Alain Bois desarrolla un argumento interesante respecto a la muerte de la pintura, "Me concentraré aquí en una afirmación específica: la de la muerte de la pintura, y más específicamente, la muerta de la pintura abstracta. El significado de esta afirmación está limitado por dos circunstancias históricas: la primera es que toda la historia de la pintura abstracta puede leerse como un anhelo de su muerte; y la segunda es la reciente aparición de un grupo de pintores neoabstractos que han sido comercializados como sus dolientes oficiales (¿o debería decir resurrectores?, pero veremos que es lo mismo)", ("I will focus here on a specific claim: that of the death of painting, and more specifically, the death of abstract painting. The meaning of this claim is bounded by two historical circumstances: the first is that the whole history of abstract painting can be read as a longing for its death; and the second is the recent emergence of a group of neoabstract painters who have been marketed as its official mourners [or should I say resurrectors? But we will see that it is the same]"), en Yve-Alain Bois, "Painting: the Task of Mourning", en Yve-Alain Bois, Painting as Model (Cambridge y Londres: MIT Press, 1993), 229-245.

70. Es interesante que tanto Thomas Puttfarken como Victor Stoichita comienzan sus libros sobre la pintura refiriéndose a la centralidad que han tenido el cuadro y la pintura en el discurso del arte. En ese sentido, es difícil pensar que no existe una pregunta sobre ese asunto cada vez que se ve una pintura. Thomas Puttfarken, The Discovery of Pictorial Composition: Theories of Visual Order in Painting, I400-I800 (New Haven: Yale University Press, 2000) y Victor I. Stoichita, La invención del cuadro: arte, artífices y artificios en los origenes de la pintura europea (Barcelona: Serbal, 2000). 
a los sujetos contemporáneos en ese flujo. ${ }^{71}$ En ese sentido, creo que la pintura contemporánea debe considerarse como un exceso, porque siempre está más allá o más acá del medio específico. Es verdad que la pintura ya no es "central", pero no sólo por los motivos que esgrime Medina en el texto sobre Alÿs. ${ }^{72}$ Desde mi perspectiva, lo que ha ocurrido es una fragmentación del medio como unidad y sus partes han salido disparadas como referencia para otros medios o como reflexión fragmentada sobre cada una de sus partes: como superficie, como color, como representación. Por supuesto eso no quiere decir que los otros medios se deriven de la pintura sino que, de alguna forma, éstos podrían tener algo de pictórico, ${ }^{73}$ así como la pintura ha perdido su carácter de unicidad. Ya no puede haber centralidad en el "cuadro", como se leía la pintura de la década de los ochenta. Pero eso no quiere decir que la pintura haya "desaparecido", a pesar del flujo de imágenes digitales. Precisamente, es por ese flujo y por la relocalización de la imagen que se ha vuelto a poner sobre la mesa este asunto. Así, la posición relativa en la que se encuentra la pintura en la actualidad la ha vuelto polisémica. Desde su carácter "tradicional y fundacional", la pintura genera una tensión con la historia que los otros medios no provocan, aunque al mismo tiempo cuestionan su actualidad. ¿¿El mito de la pintura puede seguir siendo sólo fundacional? Exclusivamente como movimiento y apertura del marco, como movimiento y desplazamiento. En definitiva, como exceso. \$

7I. Sobre ese asunto se ha escrito mucho. Se podría citar a Hito Steyerl, Los condenados de la pantalla, trad. Marcelo Expósito (Ciudad Autónoma de Buenos Aires: Caja Negra, 2014) y Boris Groys, Volverse público, trad. Paola Cortés Rocca (Ciudad Autónoma de Buenos Aires: Caja Negra, 20I4).

72. Es obvio que este análisis no es exclusivo para el trabajo de Francis Alÿs. Se podría hacer extensivo a artistas como Ilya Kabakov con sus instalaciones en las que se incluye la pintura como un elemento importante. En la obra The Blue Carpet de 1997, alrededor de una alfombra azul que abarca toda una habitación, se ponen una serie de pequeños dibujos y pinturas a ras de suelo. De hecho, es curioso que Medina no haga una reflexión, así fuera breve, del estado de la pintura en otros artistas contemporáneos en su texto sobre Alÿs.

73. Para un argumento al respecto véase Mitchell, The Picture Theory. 